\title{
A POTENT CYTOTOXICITY AND ANTIMICROBIAL ACTIVITY OF ZINC OXIDE NANOPARTICLES SYNTHESIZED BY LEAF OF IPOMOEA PES-CAPRAE (L.) R. BR.
}

\author{
RAMESH A*, SUNDARRAJ P, BALAMANI J \\ Department of Chemistry, Chikkanna Government Arts College, Tirupur, Tamil Nadu, India. Email: rammsc.perfect@gmail.com
}

Received: 01 February 2019, Revised and Accepted: 22 March 2019

\begin{abstract}
Objective: The present study was conducted to investigate the cytotoxicity and antimicrobial activity of zinc oxide nanoparticles (ZnO NPs) synthesized as eco-friendly technique from the leaf extract of Ipomoea pes-caprae (L.) R. Br. against human lung adenocarcinoma (A549), brain tumor (U87) cells,
\end{abstract} and human pathogens Salmonella typhi, Staphylococcus aureus, Klebsiella pneumonia, Pseudomonas aeruginosa, and Bacillus subtilis.

Materials and Methods: The work was carried out with varying precursor (plant extract) volume to optimize the synthesis of ZnO NPs and it was confirmed by ultraviolet (UV)-visible spectroscopy, Fourier-transform infrared spectroscopy (FTIR), X-ray diffraction (XRD) analysis, scanning electron microscopy, and atomic force microscope (AFM) characterization techniques and evaluate its cytotoxicity activity by 3-(4,5-dimethyl-2thiazolyl)-2,5-diphenyl--tetrazolium bromide assay method, antimicrobial activity by disk diffusion method.

Results: A peak at $320 \mathrm{~nm}$ with maximum intensity was observed at temperature of $80^{\circ} \mathrm{C}$ with pH of 8.0 in UV-visible spectroscopy confirmed the formation of ZnO NPs and we calculate the size of ZnO NPs from XRD data found as $15.8 \mathrm{~nm}$. The FTIR analysis evaluated that the presence of different functional groups is carboxyl, amine, and phenolic compounds of leaves extract which are involved in the reduction of zinc ions and acts as capping the ZnO NPs. AFM microgram confirms that ZnO NPs were in nanorange and spherical in nature. The cytotoxicity activity of A549 and U87 cell lines treated with various concentrations of ZnO NPs showed a dose-dependent increase in cell inhibition and the half maximal inhibitory concentration value was calculated to be $7.8 \mu \mathrm{g} / \mathrm{ml}$. The antibacterial activity of selected pathogens shows higher zone of inhibition.

Conclusion: The present study reveals that synthesized ZnO NPs capping with various bioactive compounds present in the leaf of $I$. pes-caprae show promising activity of cancer cell lines and antimicrobial agents; hence, further detailed study may lead to develop at a novel phytomedicine for the anticancer and antimicrobial drugs.

Keywords: Ipomoea pes-caprae, Zinc nanoparticles, A549 cell line, U87 cell line, Anticancer activity, Antimicrobial activity.

(C) 2019 The Authors. Published by Innovare Academic Sciences Pvt Ltd. This is an open access article under the CC BY license (http://creativecommons. org/licenses/by/4. 0/) DOI: http://dx.doi.org/10.22159/ajpcr.2019.v12i5.32318

\section{INTRODUCTION}

Recently, there is much focusing on natural products obtained from plants and herbal resources, Ipomoea pes-caprae consider as an example of phytocompounds richest resources. I. pes-caprae is used in flock medicine against inflammation and gastrointestinal disorder and as an analgesic agent [1]. I. pes-caprae is an ancient plant employed in the treatment of headache and various types of inflammation including jellyfish sting dermatitis [2]. In recent years, noble metal nanoparticles (NPs) have been the subjected of focused research due to their unique optical, electronic, mechanical, magnetic, and chemical properties that are significantly different from those of bulk materials [3]. Numerous approaches using plant extract have been used for the synthesis of metal NPs. The biosynthetic methodology employing plant extracts [4] has received much attention recently due to its simplicity, ecofriendliness, and economically viable nature, compared to the other existing methods such as using bacteria and fungi [5], and chemical [6] and physical methods used for synthesis of metal NPs. Zinc oxide NPs (ZnO NPs) have a tremendous potential in biological applications such as biological sensing [7], biological labeling, gene delivery, drug delivery [8], and nanomedicine along with its antibacterial [9], antifungal [10], acaricidal, pediculicidal, larvicidal [11], and antidiabetic activities [12]. ZnO NPs are known to be one of the multifunctional inorganic NPs with effective antibacterial activity [13]. Antibacterial and antifungal activities of $\mathrm{ZnO}$ NPs are observed even at very lower concentrations and the antifungal activity does not affect soil fertility compared to the conventional antifungal agents [14]. Based on literature, biosynthesis of ZnO NPs was reported using plant extracts including Aloe vera (leaf) [15], Nephelium lappaceum L. (fruit peel) [16], Corymbia citriodora (leaf) [17], Polygala tenuifolia (root) [18], Trifolium pratense (flower) [19], Rosa canina (fruit) [20], Zingiber officinale (rhizome) [21], Eucalyptus globulus (leaf) [22], and Vitex trifolia L. (leaf) [23]. Some reports show biosynthesized silver NPs from I. pes-caprae leaf extracts showed remarkable anticancer activity against liver cancer cells (A549) and human brain tumor cancer cell line (U87) and effective antibacterial activity [24].

In the present work, we tend to describe a green synthetic strategy to prepare ZnO NPs from leaves extract of I. pes-caprae. To confirm the presence of ZnO NPs, different characterization techniques were used and evaluate its cytotoxicity and antimicrobial activity of some selected cell lines and microbes.

\section{MATERIALS AND METHODS}

\section{Chemicals, media, and cell line}

Zinc acetate dihydrate $\left(\mathrm{Zn}\left(\mathrm{CH}_{3} \mathrm{COO}\right)_{2} \cdot 2 \mathrm{H}_{2} \mathrm{O}\right)$ was purchased from Sigma-Aldrich, Mumbai, India. High pure double distilled water was used throughout the method. Both normal and Whatman No.1 filter paper were used for the filtration process. The A549 and U87 cell lines were obtained from the National Centre for Cell Sciences (NCCS), Pune.

\section{Preparation of plant extracts}

Whole plant of I. pes-caprae was collected from Manakudi coastal area, Kanyakumari district, Tamil Nadu, India. The well-cleansed leaves were cut into smaller pieces using a sterilized knife thereafter allowed to dry in a hot air oven for $24 \mathrm{~h}$ at $40^{\circ} \mathrm{C}$. The dried, cut leaves were removed from the oven and cooled down to room temperature before grinding using a mechanical grinder. The powdered leaves were collected and 
filtered using mesh to collect very fine powder. The fine powders were then packed in airtight bags and keep for future use. From the fine powder, $5 \mathrm{~g}$ was weighed in a conical flask, to which $100 \mathrm{ml}$ of double distilled water was poured into it. The mixture was refluxed using hot plate heated around $60^{\circ} \mathrm{C}$ for $1 \mathrm{~h}$ by stirring continuously to avoid evaporation. The extract obtained was then filtered out using Whatman filter paper, and the collected extract was kept in cold condition for the future synthesis process.

\section{Phytosynthesis of ZnO NPs}

About $20 \mathrm{ml}$ of the plant extract was heated at $50^{\circ} \mathrm{C}$ for $10 \mathrm{~min}$ and $50 \mathrm{ml}$ of $91 \mathrm{mM}$ of zinc acetate solution (1 gm of zinc acetate was dissolved in $50 \mathrm{ml}$ of distilled water) was added dropwise to it under stirring. The reaction mixture became yellowish and cream-colored precipitate of zinc hydroxide was formed. The reaction mixture was left for $30 \mathrm{~min}$ for complete reduction to zinc hydroxide. Then, the precipitate was collected by centrifugation at $16,000 \mathrm{rpm}$ for $10 \mathrm{~min}$ at $4^{\circ} \mathrm{C}$. The precipitate was vacuum dried at $30^{\circ} \mathrm{C}$ and the pellet (ZnO NPs) was stored for further studies. Two other samples were prepared by varying the ratio of plant extract $(10 \mathrm{ml}$ and $30 \mathrm{ml})$ to zinc acetate $(\mathrm{v} / \mathrm{w})$ and were represented by the yield of $\mathrm{ZnO}$, calculated using the following formula:

Yield $(\%)=($ Experimental weight of $\mathrm{ZnO} /$

Theoretical weight of $\mathrm{ZnO}) \times 100$

\section{Characterization of silver NPs}

Ultraviolet (UV)-visible spectroscopy

The bioreduction of reaction mixture of the pure ZnO NPs was ascertained by observing the UV-visible spectroscopy at 200-800 nm using $1 \mathrm{ml}$ of sample, compared with $1 \mathrm{ml}$ of distilled water used as blank.

\section{Fourier-transform infrared spectroscopy (FTIR)}

To identify ZnO NPs associated biomolecules, the FTIR of powdered ZnO NPs was recorded on the Nicolet Avatar 660 FT-IR Spectroscopy using $\mathrm{KBr}$ pellets. To obtain better signal-to-noise ratio, 256 scans were taken in the range of $400-4000 \mathrm{~cm}^{-1}$ and the resolution was kept as $4 \mathrm{~cm}^{-1}$.

\section{$X$-ray diffraction $(X R D)$}

The crystalline size and purity were characterized by X-ray diffractometer (Bruker D8 Advance) using $\mathrm{Cu}-\mathrm{Ka}$ radiation of wavelength $\mathrm{k}=1.541 \mathrm{~A}$ of synthesized ZnO NPs. The particle size of the prepared samples was determined using the Scherrer's equation as follows: $D \approx 0.9 / \cos \theta$, where, $D$ is the crystal size, $k$ is the wavelength of X-ray, $\mathrm{h}$ is the Braggs angle in radians, and $\mathrm{B}$ is the full width at half maximum (FWHM) of the peak in radians.

\section{Scanning electron microscopy (SEM)}

CARL ZEISS EV018 SEM machine was used to characterize the morphology of ZnO NPs. Thin films of the sample were prepared on a carbon-coated copper grid by simply dropping a very small amount of the sample on the grid, extra solution was removed using a blotting paper, and then, the film on the SEM grid could dry by putting it under a mercury lamp for $5 \mathrm{~min}$. The photographs were captured in SEM mode at the desired magnification.

\section{Atomic force microscope (AFM) analysis}

The synthesized NPs were spreading on the glass slides then dried and subjected for characterization to find morphological and structural properties by AFM AGILENT-N9410A-5500.

\section{Biological application}

Antibacterial activity

The antibacterial activity of the ZnO NPs was evaluated against Salmonella typhi, Staphylococcus aureus, Klebsiella pneumonia,
Pseudomonas aeruginosa, and Bacillus subtilis using agar well diffusion method. The antibacterial effect of ZnO NPs has been reported against Gram-positive and Gram-negative bacteria due to larger surface area and electrostatic interaction of NPs. Stock cultures were maintained at $4^{\circ} \mathrm{C}$ on nutrient agar slant. Active cultures for experiments were prepared by transferring a loop full of culture from the stock cultures into the test tubes containing nutrient broth that was incubated at $24 \mathrm{~h}$ at $37^{\circ} \mathrm{C}$. Antibacterial activity of extracts was determined by agar disc diffusion method on Mueller-Hinton agar (MHA) medium. MHA medium is poured into the Petri plate. Once the medium was solidified, the inoculums were spread on the solid plates with sterile swab moistened with the bacterial suspension. Different concentrations of the sample were prepared $(1000 \mu \mathrm{g}, 750 \mu \mathrm{g}$, and $500 \mu \mathrm{g}) .20 \mu \mathrm{l}$ of sample from each concentration was taken and added into the sterile discs and air dried. Then, the sample loaded disc was placed on the MHA plates along with positive control and incubated at $37^{\circ} \mathrm{C}$ for $24 \mathrm{~h}$, and the antimicrobial activity was determined by measuring the diameter of zone of inhibition.

\section{Cytotoxicity studies}

Liver cancer cells (A549), and human brain tumor cancer (U87) cell lines were purchased from NCCS, Pune, India. It was cultured in Dulbecco's modified Eagle's Medium (DMEM, HiMedia Laboratories, Mumbai, India), supplemented with $10 \%$ fetal bovine serum and $1 \%$ penicillin/streptomycin (HiMedia Laboratories, Mumbai, India). The cell lines were maintained at $5 \% \mathrm{CO}_{2}$ in $\mathrm{CO}_{2}$ incubator. Cultures were examined using an inverted microscope to evaluate the quality of confluence and confirming the absence of bacterial and fungal contaminants.

\section{3-(4,5-dimethyl-2-thiazolyl)-2,5-diphenyl-tetrazolium bromide (MTT) assay}

To determine the cytotoxic effect of ZnO NPs synthesized from I. pescaprae leaves extract, cell viability study was carried out with the MTT reduction assay. A549 and U87 cells $\left(1 \times 10^{5} /\right.$ well) were plated in $24-$ well plates and incubated in $37^{\circ} \mathrm{C}$ with $5 \% \mathrm{CO}_{2}$ condition. After the cell reaches the confluence, the various concentrations of the ZnO NPs were added and incubated for $24 \mathrm{~h}$. After incubation, the sample was removed from the well and washed with phosphate-buffered saline (pH 7.4) or DMEM without serum. $100 \mu \mathrm{l} /$ well $(5 \mathrm{mg} / \mathrm{ml})$ of $0.5 \%$ MTT was added and incubated for $4 \mathrm{~h}$. After incubation, $1 \mathrm{ml}$ of dimethyl sulfoxide (DMSO) was added in all the wells. The absorbance at $570 \mathrm{~nm}$ was measured with UV spectrophotometer using DMSO as the blank. Measurements were performed and the concentration required for a $50 \%$ inhibition (half maximal inhibitory concentration $\left[\mathrm{IC}_{50}\right]$ ) was determined graphically. The percentage of cell viability was calculated using the following formula:

$$
\text { Percentage of cell viability }=\frac{\text { O.D of treated cells }}{\text { O.D of control cells }} \times 100
$$

Graphs were plotted using the percentage of cell viability at Y-axis and concentration of the sample in X-axis. Cell control and sample control are included in each assay to compare the full cell viability assessments.

\section{RESULTS AND DISCUSSION}

\section{Effect of plant extract concentration on ZnO NP synthesis}

Concentration of plant extract plays a key role in the synthesis of $\mathrm{ZnO}$ NPs. It has been observed that the ratio of plant extract to zinc acetate $20 \mathrm{ml} / \mathrm{gm}$ (i.e., $1 \mathrm{gm}$ of zinc acetate in $20 \mathrm{ml}$ of plant extract) was optimal concentration for the synthesis of ZnO NPs which gives yield 95\%. Insufficient amount of bioactive compound present in $10 \mathrm{ml} / \mathrm{gm}$ of zinc acetate lowers the yield of ZnO NPs gives $70 \%$, whereas $30 \mathrm{ml} / \mathrm{gm}$ of zinc acetate yield $95 \%$ nearly same amounts of ZnO NPs that yield in $20 \mathrm{ml} / \mathrm{gm}$ (Fig. 1). That means, the number of bioactive compounds present in case of $20 \mathrm{ml} / \mathrm{gm}$ was sufficient to reduce all $\mathrm{Zn}^{2+}$ ions present in the reaction mixture. 
Characterization of synthesized ZnO NPs

$U V$-visible spectrum

UV-visible spectroscopy used to identify the synthesis of ZnO NPs (Fig. 2) represents the formation of ZnO NPs. Freshly prepared ZnO suspensions in plant extract exhibit a strong absorption at $320 \mathrm{~nm}$ in the UV region. This surface plasmon resonance band undergoes a red or blue shift, depending on the quantum size effects. The absorbance

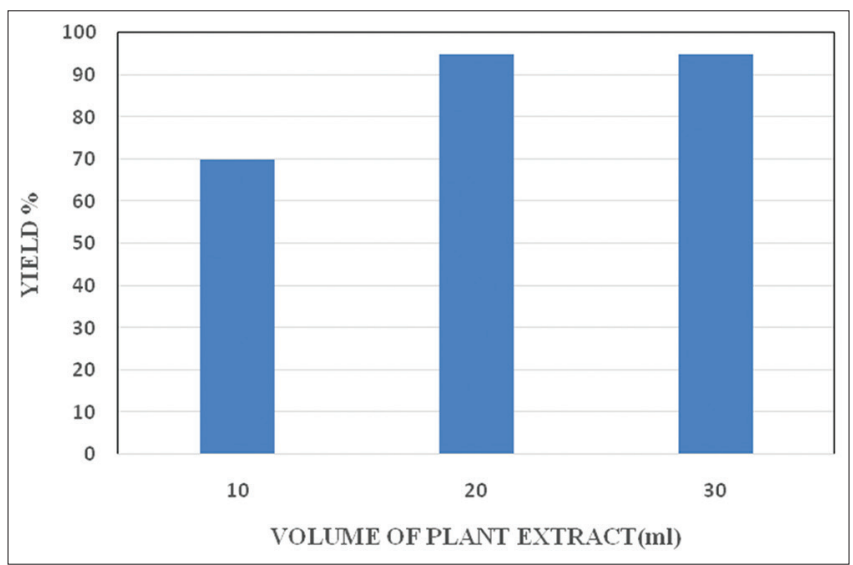

Fig. 1: Effect of plant extract concentration in synthesis of zinc oxide nanoparticles

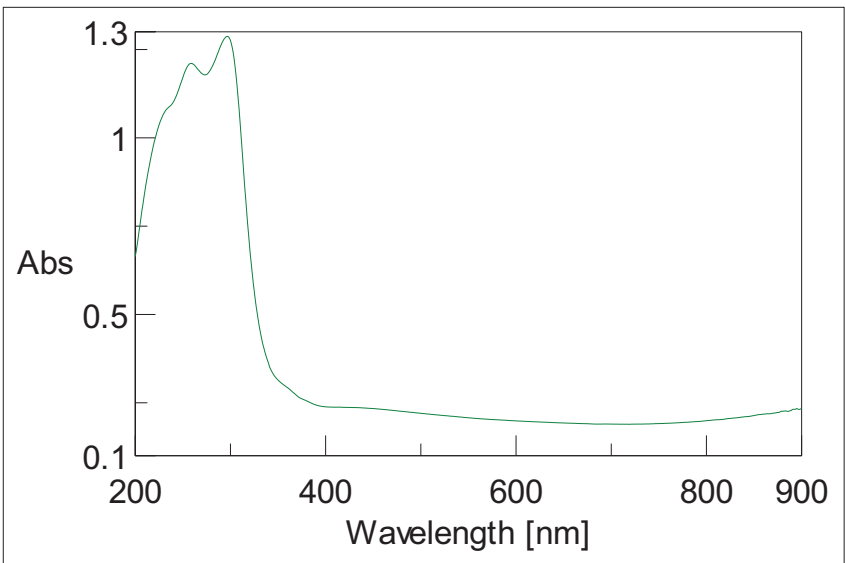

Fig. 2: Ultraviolet-visible absorption spectrum of zinc oxide nanoparticles synthesized from Ipomoea pes-caprae leaves extract of ZnO NPs depends on their shape and size. The plant extract reacts with $\mathrm{Zn}^{2+}$ ions reduces the precursor solution and formation of NPs monitored by UV-visible spectroscopy.

\section{FTIR analysis}

The FTIR spectrum of I. pes-caprae leaves extract and synthesized ZnO NPs (Fig. 3) showed strong IR bands characteristic of carboxylic acids $\left(1030 \mathrm{~cm}^{-1}\right)$, amines $\left(1622 \mathrm{~cm}^{-1}\right)$, alkanes $\left(2923\right.$ and $\left.2853 \mathrm{~cm}^{-1}\right), 0-\mathrm{H}$ carboxylic acids $\left(2362 \mathrm{~cm}^{-1}\right)$, and hydrogen bonded alcohols $\left(3416 \mathrm{~cm}^{-1}\right)$ functional groups. The band at $3424.94 \mathrm{~cm}^{-1}$ that corresponds to normal "polymeric" OH stretching mode. The peak at $2923 \mathrm{~cm}^{-1}$ associated to the methylene $\mathrm{C}-\mathrm{H}$ asymmetric and symmetric stretching mode. The peak at $2362 \mathrm{~cm}^{-1}$ indicates the symmetric stretching of alkanes and the peak at $1622 \mathrm{~cm}^{-1}$ attributed to the $\mathrm{C}=0$ stretching mode of ketones. The peak at $1384 \mathrm{~cm}^{-1}$ corresponds to the $\mathrm{N}=0$ stretching of nitro groups of leaves extract. Here, we confirm the modulated transmittance percentage of ketone, polymeric $\mathrm{OH}$ compounds, and amine groups play a key role for the bioreduction of $\mathrm{Zn}^{2+}$ to $\mathrm{ZnO}$ NPs. The FTIR analysis strongly supported the capping behavior of bioreduced ZnO NPs synthesized by I. pes-caprae leaves extracts which, in turn, imparted the high stability of the synthesized NPs.

\section{XRD analysis}

The XRD spectra of I. pes-caprae leaf aqueous extract mediated ZnO NPs are shown in Fig. 4. The prominent peaks corresponding to the diffraction planes (100), (002), (101), (012), (102), (110), (103), (200), (112), (201), and (202) agreed well with the JCPDS Card No. 36-1451, confirming the hexagonal wurtzite structure of the ZnO NPs. The strong intensity and broadened diffraction peaks clearly indicate that the $\mathrm{ZnO}$ NPs are highly crystalline in nature. Similar results are obtained by Yu et al. [25]. The average particle size (D) of synthesized NPs was calculated using the well-known Scherrer formula $\mathrm{D}=0.9 \mathrm{k} / \mathrm{b} \cos \theta$, where, $\mathrm{k}$ is the wavelength of X-ray source ( $\mathrm{Cu}$-Ka line $-0.1541 \mathrm{~nm}$ ), b is the FWHM in radians, and $\mathrm{h}$ is Bragg's diffraction angle. The calculated value of D was $15.8 \mathrm{~nm}$.

\section{SEM}

The shape, structure, and size of the ZnO NP synthesized using leaf extracts of I. pes-caprae was determined by the SEM analysis (Fig. 5) and an average size of about $27 \mathrm{~nm}$ was seen in the $\mathrm{ZnO}$ NP. The previous studies showed that the $\mathrm{ZnO} \mathrm{NPs}$ were in the range of $37 \mathrm{~nm}$ and these were in accordance to our present study [26].

\section{AFM}

The AFM of 2D and 3D result images that shown in Fig. 6 showed the morphological and structural characterization of green synthesized

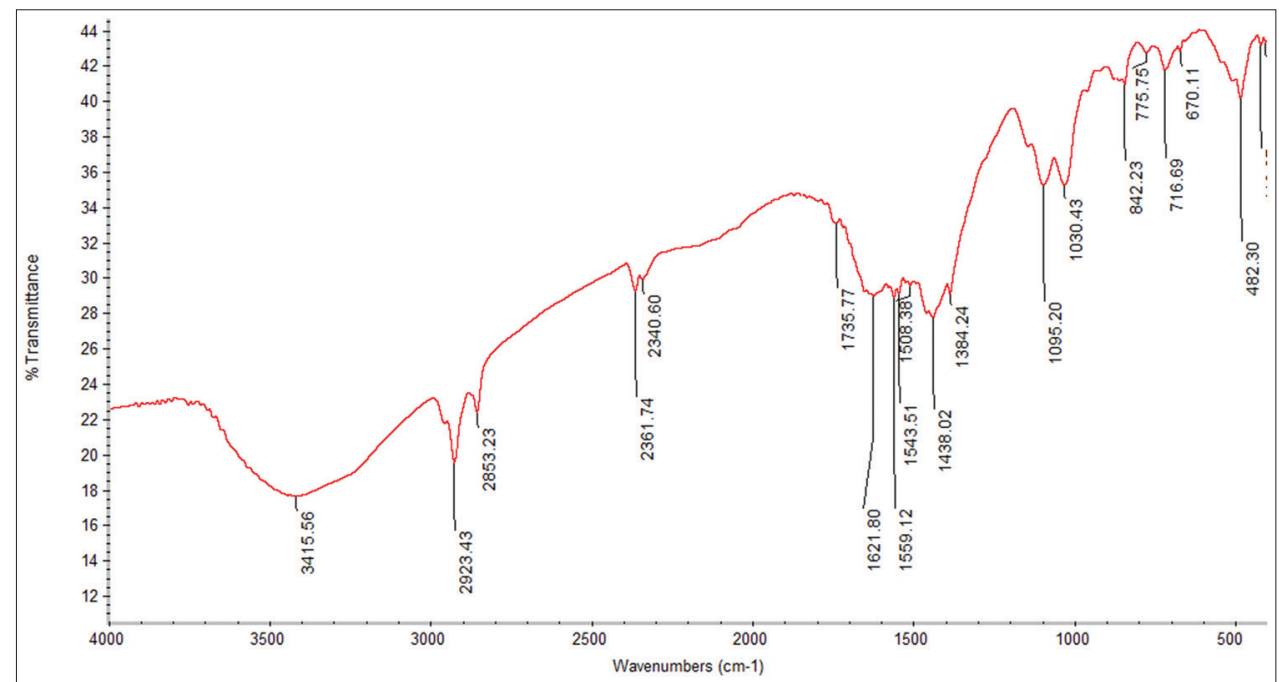

Fig. 3: Fourier-transform infrared spectroscopy spectrum of synthesized zinc oxide nanoparticles 
Table 1: Antibacterial activity of the ZnO NPs synthesized by I. pes-caprae leaves extract

\begin{tabular}{|c|c|c|c|c|}
\hline \multirow[t]{2}{*}{ Bacterium name } & \multicolumn{4}{|l|}{ Zone of inhibition (mm) } \\
\hline & Control (ampicillin) $1000 \mu \mathrm{g} / \mathrm{mL}$ & $1000 \mu \mathrm{g} / \mathrm{ml}$ & $750 \mu \mathrm{g} / \mathrm{ml}$ & $500 \mu \mathrm{g} / \mathrm{ml}$ \\
\hline Staphylococcus aureus & 21 & 11 & 9 & 9 \\
\hline Bacillus subtilis & 23 & 12 & 9 & 8 \\
\hline Klebsiella pneumoniae & 18 & 13 & 10 & 9 \\
\hline Salmonella typhi & 47 & 20 & 11 & 9 \\
\hline Pseudomonas aeruginosa & 25 & 15 & 11 & 10 \\
\hline
\end{tabular}

Table 2: Cytotoxicity activity of the ZnO NPs synthesized by I. pes-caprae leaves extract

\begin{tabular}{|c|c|c|c|c|c|c|}
\hline \multirow[t]{2}{*}{ S. No. } & \multirow[t]{2}{*}{ Concentration $(\mu \mathrm{g} / \mathrm{ml})$} & \multirow[t]{2}{*}{ Dilution } & \multicolumn{2}{|c|}{ Absorbance (O.D) } & \multicolumn{2}{|c|}{ Cell viability (\%) } \\
\hline & & & A549 & U87 & A549 & U87 \\
\hline 1 & 1000 & Neat & 0.116 & 0.082 & 11.98 & 11.76 \\
\hline 2 & 500 & $1: 1$ & 0.162 & 0.109 & 16.73 & 15.63 \\
\hline 3 & 250 & $1: 2$ & 0.211 & 0.135 & 21.79 & 19.36 \\
\hline 4 & 125 & $1: 4$ & 0.264 & 0.172 & 27.27 & 24.67 \\
\hline 5 & 62.5 & $1: 8$ & 0.326 & 0.212 & 33.67 & 30.41 \\
\hline 6 & 31.2 & $1: 16$ & 0.389 & 0.246 & 40.18 & 35.29 \\
\hline 7 & 15.6 & $1: 32$ & 0.453 & 0.286 & 46.79 & 41.03 \\
\hline 8 & 7.8 & $1: 64$ & 0.512 & 0.338 & 52.89 & 48.49 \\
\hline 9 & Cell control & & 0.968 & 0.697 & 100 & 100 \\
\hline
\end{tabular}

I. pes-caprae: Ipomoea pes-caprae, ZnO NPs: Zinc oxide nanoparticles

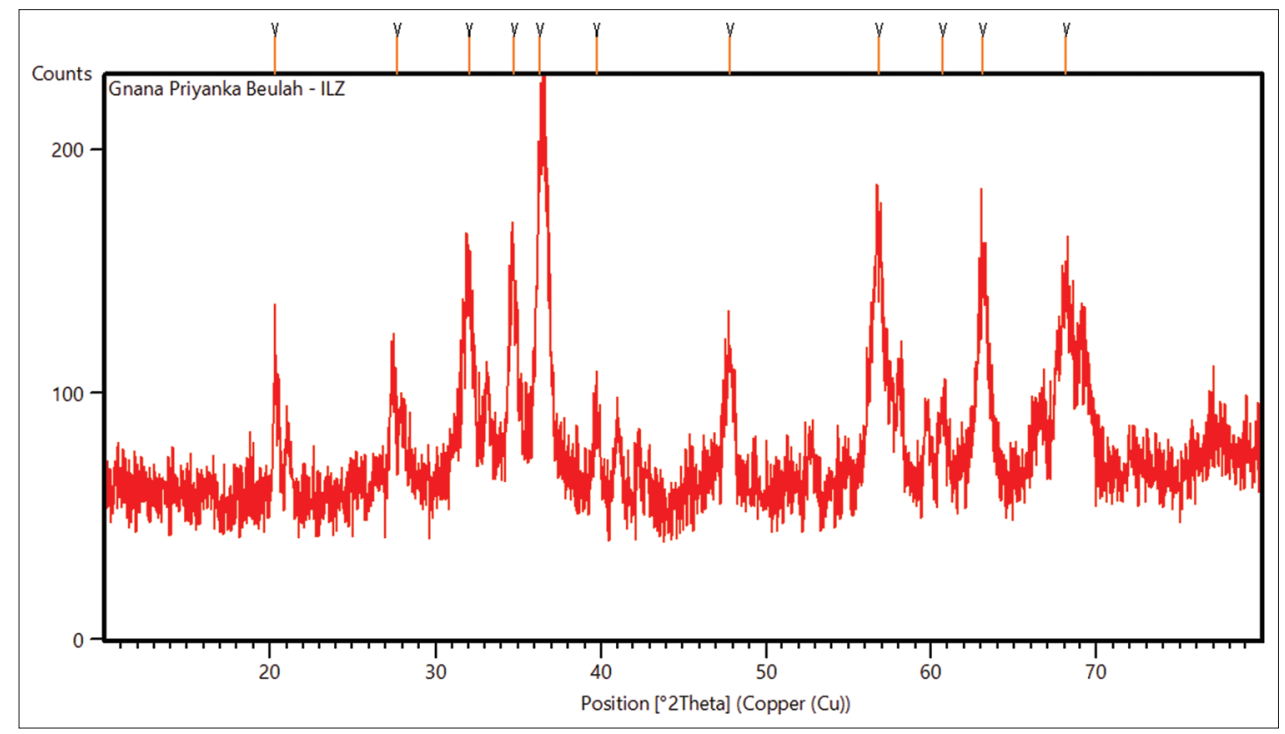

Fig. 4: X-ray diffraction spectra of zinc oxide nanoparticles using Ipomoea pes-caprae leaves aqueous extract
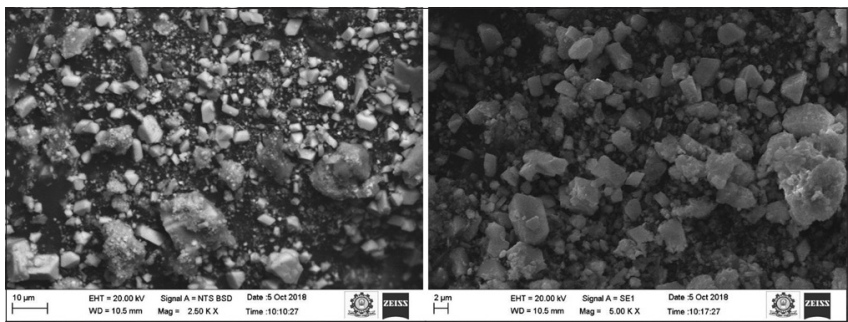

Fig. 5: Scanning electron microscopy images of zinc oxide nanoparticles using Ipomoea pes-caprae leaves extract

ZnO NPs by I. pes-caprae leaves extract with average diameter of $40 \mathrm{~nm}$. From the figure concluded that NPs are equal in size and their morphology also rough in nature cubical in shape.

\section{Biological applications of ZnO NPs}

Antibacterial activity

Synthesized ZnO NPs were analyzed by disk diffusion method using selected organisms such as S. typhi, S. aureus, K. pneumonia, P. aeruginosa, and B. Subtilis is shown in Fig.7. As the concentration of ZnO NPs increases, the zone of inhibition also increased against the bacteria strain is shown in Table $1 . \mathrm{ZnO}$ NPs synthesized from leaves extract exhibited significant activity against $S$. typhi and P. aeruginosa with zone of inhibition 20 and $15 \mathrm{~mm}$ is shown in Fig.8. This proves that the ZnO NPs synthesized by the simple solution method may be used for microbial activity study.

Finally, the current study clearly indicates that the synthesized ZnO NPs exhibit the zone of inhibition have high value obtained at Gramnegative organisms of S. typhi and P. aeruginosa. These plant-mediated $\mathrm{ZnO}$ NPs show high antibacterial activity which may be used in textiles coatings and wood flooring as antibacterial agents. 


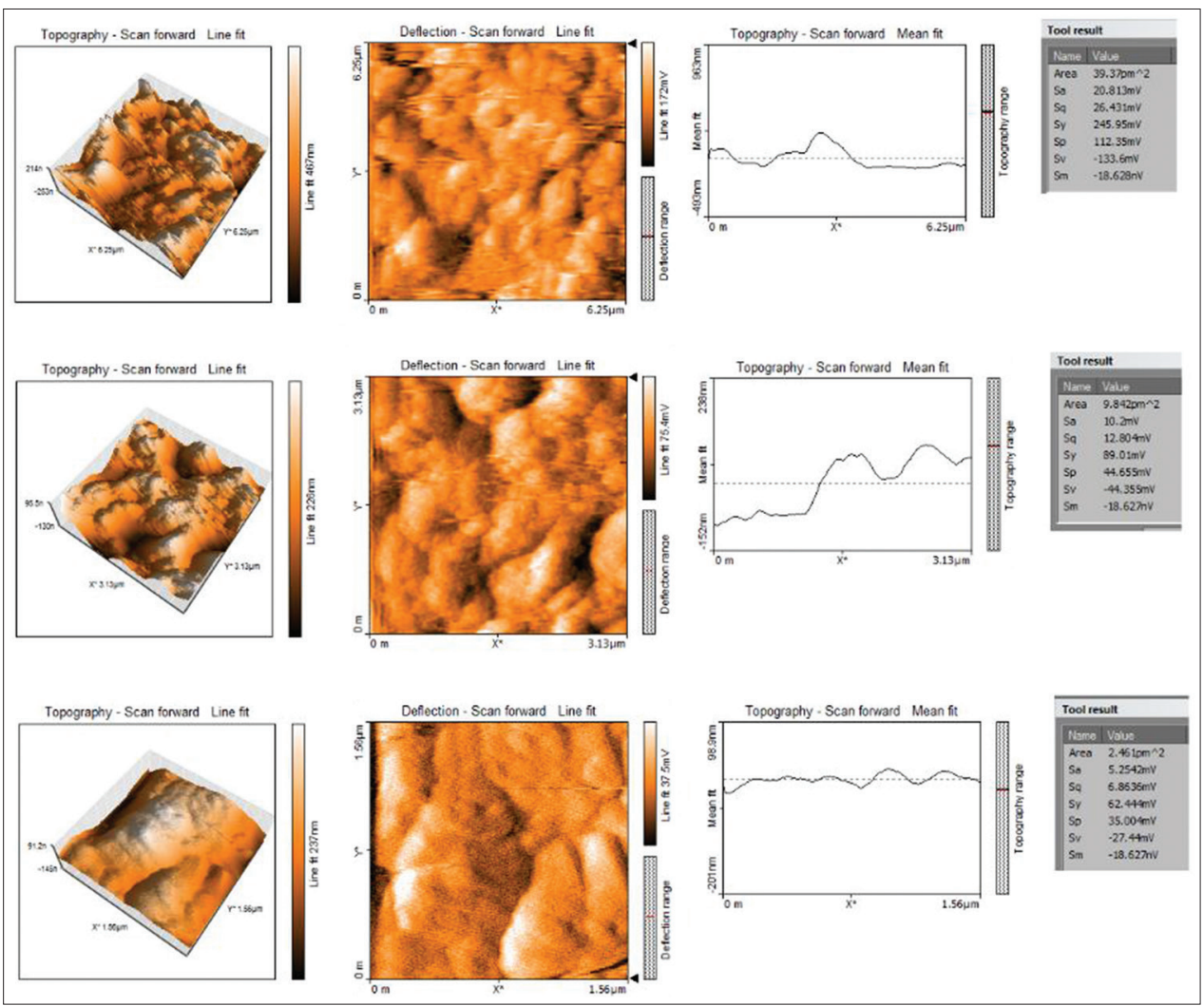

Fig. 6: Atomic force microscope images of zinc oxide nanoparticles synthesized by Ipomoea pes-caprae leaf extract

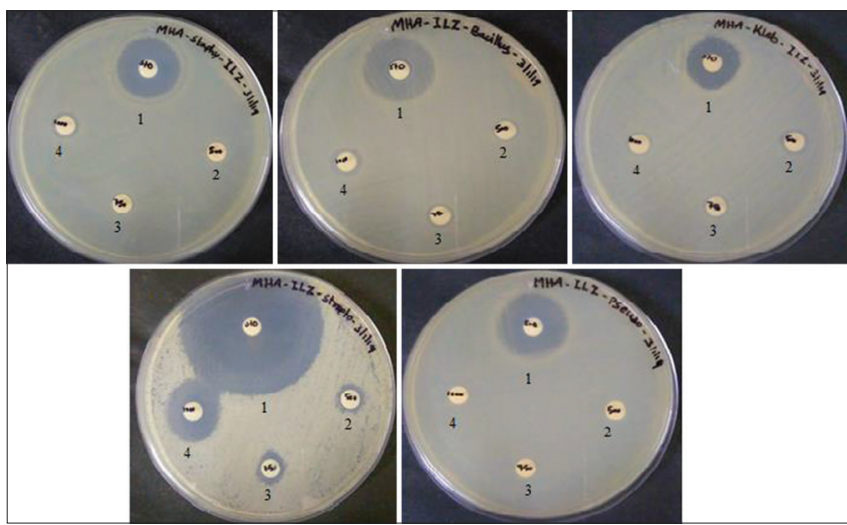

Fig. 7: The antibacterial activity of zinc oxide nanoparticles from leaves extract in (a) Staphylococcus aureus, (b) Bacillus subtilis (c) Klebsiella pneumonia, (d) Salmonella typhi, (e) Pseudomonas aeruginosa, at various concentrations ([1] Positive control, [2] $500 \mu \mathrm{g} / \mathrm{ml},[3] 750 \mu \mathrm{g} / \mathrm{ml}$, and [4] $1000 \mu \mathrm{g} / \mathrm{ml}$ )

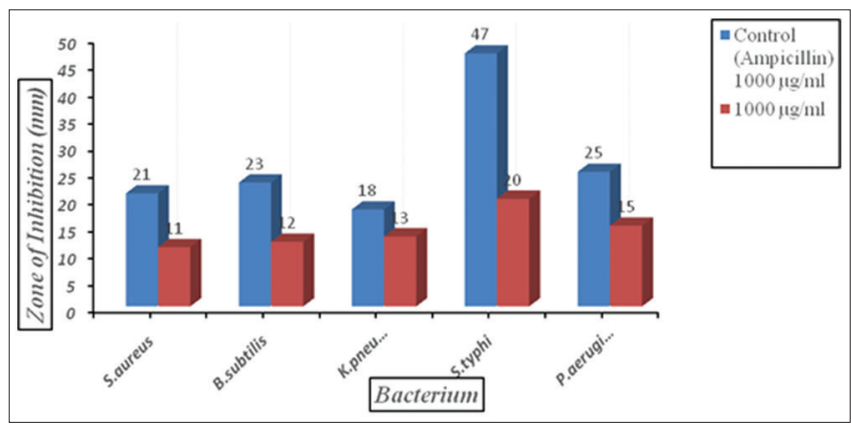

Fig. 8: Effect of antibacterial activity of zinc oxide nanoparticles from leaves extract with positive control

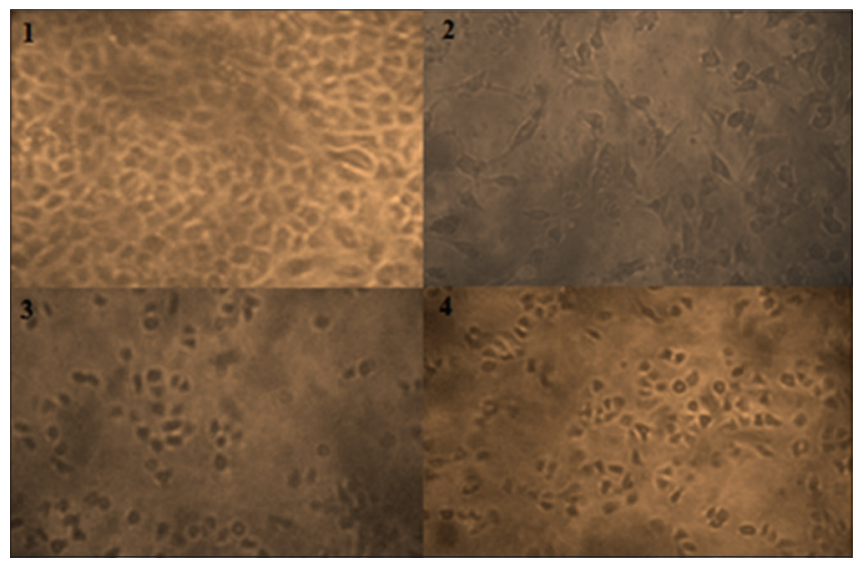

Fig. 9: Anticancer activity of zinc oxide nanoparticles from leaves extract of Ipomoea pes-caprae in A549 cell line ([1] Normal A549 cell line, [2] Toxicity - $1000 \mu \mathrm{g} / \mathrm{ml}$, [3] Toxicity $-62.5 \mu \mathrm{g} / \mathrm{ml}$, and [4] Toxicity $-7.8 \mu \mathrm{g} / \mathrm{ml}$ )

\section{Cytotoxicity analysis}

The cytotoxicity of the ZnO NPs synthesized from I. pes-caprae leaves extract was studied against the A549 (Fig. 9) and U87 (Fig. 10) cell line by MTT assay. The cytotoxicity effect of cancer cell was studied at different concentrations $(1000 \mu \mathrm{g} / \mathrm{ml}-7.8 \mu \mathrm{g} / \mathrm{ml})$ is shown in Table 2 . The IC ${ }_{50}$ value of the phyto-mediated ZnO NPs of leaves extract at the cell viability of $52.9 \%$ (Fig. 11) against A549 cells was observed at 7.8 $\mu \mathrm{g} / \mathrm{ml}$ and for U87 cells was observed as $48.5 \%$ at the concentration of $7.8 \mu \mathrm{g} / \mathrm{ml}$ (Fig. 12). This study shows that the minimum dose showed significant anticancer activity. Some reports exhibit that $\mathrm{ZnO}$ NPs may stimulate reactive oxygen species and effect in damage cellular components which lead to cell death [27]. Some reports show that ZnO NPs were induced greater cytotoxicity in the colon, liver, lung, and skin cells at higher concentrations of 100 and $300 \mu \mathrm{g} / \mathrm{ml}$ significantly [28]. 


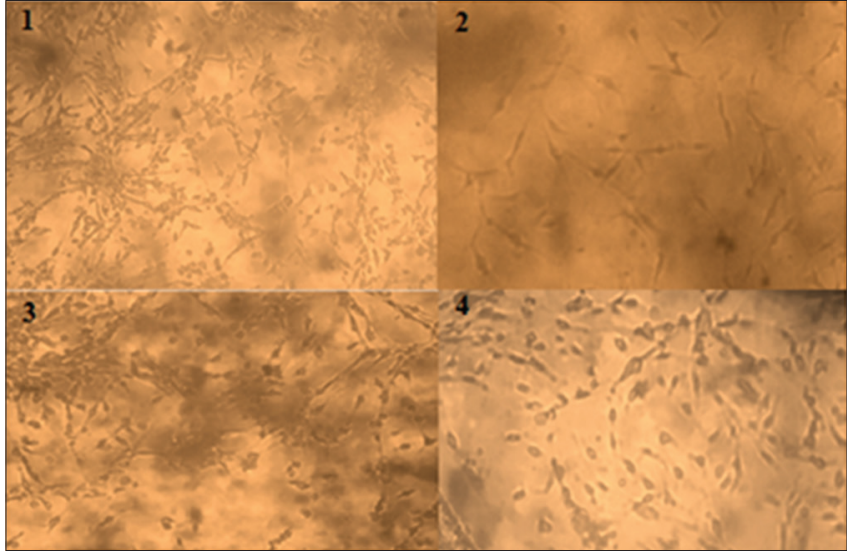

Fig. 10: Anticancer activity of zinc oxide nanoparticles from leaves extract of Ipomoea pes-caprae in U87 cell line ([1] Normal U87 cell line, [2] Toxicity $-1000 \mu \mathrm{g} / \mathrm{ml}$, [3] Toxicity $-62.5 \mu \mathrm{g} / \mathrm{ml}$, and [4] Toxicity $-7.8 \mu \mathrm{g} / \mathrm{ml}$ )

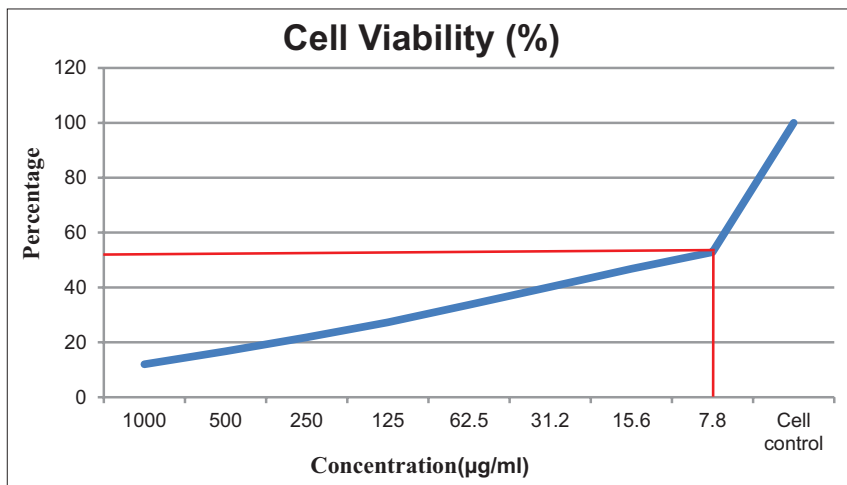

Fig. 11: Half maximal inhibitory concentration value of zinc oxide nanoparticles from leaves extract against A549 cell line

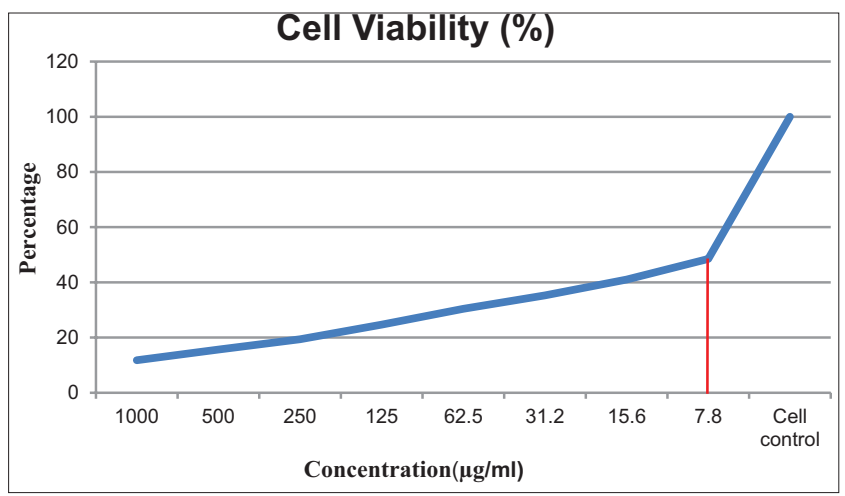

Fig. 12: Half maximal inhibitory concentration value of zinc oxide nanoparticles from leaves extract against U87 cell line

\section{CONCLUSION}

We report a simple straight forward, facile, inexpensive, eco-friendly, and green synthesis of ZnO NPs from I. pes-caprae leaves in aqueous medium without employing man-made chemicals. The UV-visible spectroscopy and FT-IR analysis are confirmed the preliminary confirmation of the formation of ZnO NPs. AFM image showed cubical shape with an average particle size of $40 \mathrm{~nm}$. The biosynthesized ZnO NPs from I. pes-caprae leaf extracts showed remarkable anticancer activity against liver cancer cells (A549) and human brain tumor cancer cell line (U87) and effective antibacterial activity. From the study, it can be concluded that the $\mathrm{ZnO}$ NPs synthesized using plant possess high anticancer and antibacterial activity which further suggested the potential therapeutic use of these NPs.

\section{ACKNOWLEDGMENT}

We would like to acknowledge Dr. I Seethalakshmi, Director, Life Teck Research Centre, Chennai, for his professional helping hand in biological studies.

\section{AUTHORS' CONTRIBUTIONS}

The present work selection, procurement, synthesis, and biological studies were done by Mr. A Ramesh and wrote the manuscript under the supervision of Prof. J Balamani.

\section{CONFLICTS OF INTEREST}

The authors declare that there were no conflicts of interest.

\section{REFERENCES}

1. Souza MM, Madeira A, Berti C, Krogh R, Yunes RA, Cechinel-Filho V. Antinociceptive properties of the methanolic extract obtained from Ipomoea pes-caprae (L.)R. Br J Ethnopharmacol 2000;69:85-90.

2. Bandaranayake WM. Bioactivities, bioactive compounds and chemical constituents of mangrove plants. Wetl Ecol Manag 2002;10:421-52.

3. Gavhane AJ, Padmanabhan P, Kamble SP, Jangle SN. Synthesis of silver nanoparticles using extract of neem leaf and triphala and evaluation of their antimicrobial activities. Int J Pharm Bio Sci 2012;42:20-31.

4. Dhanalakshmi T, Rajendran S. Synthesis of silver nanoparticles using Tridax procumbens and its antimicrobial activity. Sch Res Libr Arch Appl Sci Res 2012;4:1289-93.

5. Oza G, Pandey S, Shah R, Sharon M. Extracellular fabrication of silver nanoparticles using Pseudomonas aeruginosa and its antimicrobial assay. Pelagia Res Libr Adv Appl Sci Res 2012;3:1776-83.

6. El-Kheshen AA, El-Rab SF. Effect of reducing and protecting agents on size of silver nanoparticles and their anti-bacterial activity. Der Pharm Chem 2012;4:55-63.

7. Yoon SH, Kim DJ. Fabrication and Characterization of $\mathrm{ZnO}$ Films for Biological Sensor Application of FPW Device. Applications of Ferroelectrics. $15^{\text {th }}$ IEEE International Symposium on the July 30; 2006. p. 322-5.

8. Rasmussen JW, Martinez E, Louka P, Wingett DG. Zinc oxide nanoparticles for selective destruction of tumor cells and potential for drug delivery applications. Expert Opin Drug Deliv 2010;7:1063-77.

9. Applerot G, Lipovsky A, Dror R, Perkas N. Enhanced antibacterial activity of nanocrystalline $\mathrm{ZnO}$ due to increased ROS-mediated cell injury. Adv Funct Mater 2009;19:842-52.

10. Sharmaa D, Rajputa J, Kaitha BS, Kaurb M. Synthesis of ZnO nanoparticles and study of their antibacterial and antifungal properties. Thin Solid Films 2010;519:1224-9.

11. Kirthi AV, Rahuman AA, Rajakumar G, Marimuthu S, Santhoshkumar T, Jayaseelan C, et al. Acaricidal, pediculocidal and larvicidal activity of synthesized znO nanoparticles using wet chemical route against blood feeding parasites. Parasitol Res 2011;109:461-72.

12. Alkaladi A, Abdelazim AM, Afifi M. Antidiabetic activity of zinc oxide and silver nanoparticles on streptozotocin-induced diabetic rats. Int $\mathrm{J}$ Mol Sci 2014; 15:2015-23

13. Gunalana S, Sivaraja R, Rajendranb V. Green synthesized ZnO nanoparticles against bacterial and fungal pathogens. Prog Nat Sci Mater Int 2012;22:693-700.

14. Feris K, Otto C, Tinker J, Wingett D, Punnoose A, Thurber A, et al. Electrostatic interactions affect nanoparticle-mediated toxicity to gram-negative bacterium Pseudomonas aeruginosa PAO1. Langmuir 2010;26:4429-36.

15. Ali K, Dwivedi S, Azam A, Saquib Q, Al-Said MS, Alkhedhairy A, et al. Aloe vera extract functionalized zinc oxide nanoparticles as nanoantibiotics against multi-drug resistant clinical bacterial isolates. J Colloid Interface Sci 2016;472:145-56

16. Karnan T, Stanly AS. Biosynthesis of ZnO nanoparticles using rambutan (Nephelium lappaceum L.) peel extract and their photocatalytic activity on methyl orange dye. J Mol Struct 2016;1125:358-65.

17. Zheng Y, Fu L, Han F, Wang A, Cai W, Yu J, et al. Green biosynthesis and characterization of zinc oxide nanoparticles using Corymbia citriodora leaf extract and their photocatalytic activity. Green Chem Lett Rev 2015;8:59-63. 
18. Nagajyothi PC, Ju S, Jun I, Sreekanth TV, Joong K, Mook H. Antioxidant and anti-inflammatory activities of zinc oxide nanoparticles synthesized using Polygala tenuifolia root extract. J Photochem Photobiol B 2015;146:10-7.

19. Dobrucka R, Długaszewska J. Biosynthesis and antibacterial activity of $\mathrm{ZnO}$ nanoparticles using Trifolium pratense flower extract. Saudi J Biol Sci 2001;23:517-23

20. Jafarirad S, Mehrabi M, Divband B, Kosari-NasabM. Biofabrication of zinc oxide nanoparticles using fruit extract of Rosa canina and their toxic potential against bacteria: A mechanistic approach. Mater Sci Eng C 2016;59:296-302.

21. Anbuvannan M, Ramesh M, Viruthagiri G, Shanmugam N, Kannadasan N. Synthesis, characterization and photocatalytic activity of $\mathrm{ZnO}$ nanoparticles prepared by biological method. Spectrochim Acta Part A 2015;143:304-8.

22. Balaji S, Kumar MB. Facile green synthesis of zinc oxide nanoparticles by Eucalyptus globulus and their photocatalytic and antioxidant activity. Adv Powder Technol 2017;28:785-97.

23. Elumalai K, Velmurugan S, Ravi S, Kathiravan V, Raj GA. Bio- approach: Plant mediated synthesis of $\mathrm{ZnO}$ nanoparticles and their catalytic reduction of methylene blue and antimicrobial activity. Soc Powder Technol Jpn 2015;26:1639-51.

24. Ramesh A, Sundarraj P, Balamani J. Characterization and biological evaluation of silver nanoparticles synthesized by leaf extracts of Ipomoea pes-caprae (L) R. BR. JETIR 2018;5:510-20.

25. Yu ZJ, Kumar MR, Sun DL, Wang LT, Hong RY. Large scale production of hexagonal $\mathrm{ZnO}$ nanoparticles using PVP as a surfactant. Mater Lett 2016;166:284-7.

26. Raj LF, Jayalakshmy E. A biogenic approach for the synthesis and characterization of zinc oxide nanoparticles produced by Tinospora cordifolia. Int J Pharm Pharm Sci 2015;7:384-6.

27. Jacob JP, Finub S, Narayanan A. Synthesis of silver nanoparticles using Piper longum leaf extracts and its cytotoxic activity against Hep-2 cell line. Colloids Surf B Biointerfaces 2012;91:212-6.

28. Durgaiah G, Harikiran L, Narsimha RY. Cytotoxicity evaluation of titanium and zinc oxide nanoparticles on human cell lines. Int J Pharm Pharm Sci 2017;11:240-6. 